\title{
Understanding why fat, oil and grease (FOG) bioremediation can be unsuccessful
}

C. Gurd ${ }^{1}$, R. Villa ${ }^{2 *}$ and B. Jefferson ${ }^{1}$

${ }^{1}$ Cranfield University, Cranfield, MK43 OAL, Bedfordshire (UK)

${ }^{2}$ De Montfort University, Leicester, LE1 9HB, Leicestershire (UK)

Corresponding author: r.villa@dmu.ac.uk

\section{Highlights}

- FOG biodegradation rates varied with wastewater composition between 5 - 26 $\mathrm{mg} / \mathrm{l} / \mathrm{h}$.

- FOG removal decreased from 24 to $10 \mathrm{mg} / \mathrm{l} / \mathrm{h}$ when glucose was substitute for starch.

- FOG removal was inversely related to initial COD:N.

- FOG removal started in the stationary phase of bacterial growth in all wastewaters.

\section{Graphical Abtract}

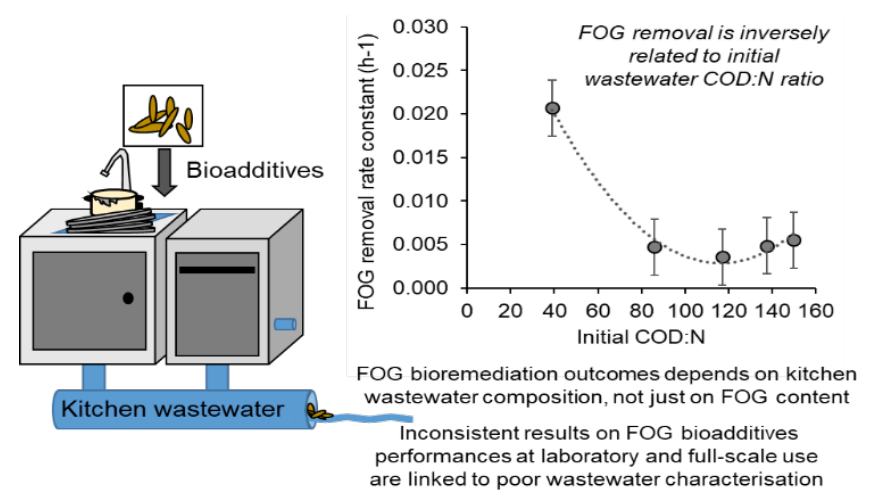

\section{Abstract}

Commercial kitchen wastewaters are typically strong organic and fat-rich effluents, often identified as major contributors to fatberg formation and associated blockages in sewers. Experimental trials were done using synthetic kitchen wastewater to understand the complex reactions involved in microbial remediation in grease traps/separators prior discharge in sewers. The principle organic components (FOG, carbohydrate and protein nitrogen), were varied using ranges observed in a previous study on real kitchen wastewater characterisation. A model bacterium, Bacillus licheniformis NCIMB 9375, was used to evaluate microbial utilisation of the different organic fractions in relation to fat, oil and grease (FOG) degradation. Novel results in the treatment of these effluents showed that, the presence and concentration of alternative carbon sources and the ratio of carbon to nitrogen (COD:N) had great influence on FOGdegradation response. For example, FOG removal decreased from 24 to 10 $\mathrm{mg} / \mathrm{/} / \mathrm{h}$ when glucose was substitute for starch at equivalent concentrations $(500 \mathrm{mg} / \mathrm{l})$; and from 26 to $5 \mathrm{mg} / \mathrm{l} / \mathrm{h}$ when initial COD:N increased from $45: 1$ to 147:1. The dominant influence of COD: $\mathrm{N}$ was validated using a commercial bioadditive and real kitchen wastewater adjusted to different COD:N ratios, confirming the strong influence of kitchen wastewater composition on bioremediation outcomes. These results can therefore have major implications for biological management of FOG in kitchens and sewers as they provide a scientific explanation for bioremediation success or failure.

Keywords: bioadditives; bioadditions; kitchen wastewater; fatberg; lipids; FOG 


\section{Introduction}

A wide variety of industrial, commercial and domestic establishments produce wastewater rich in fats, oils and greases (FOGs) which can form deposits in sewer pipes and contribute to the formation of sewers' fatbergs (Brooksbank et al., 2007; Montefrio et al., 2010). Alongside physical processes (i.e. grease separators), these FOG discharges can be managed with biological products (or bioadditions), which can be added to a grease separator/trap or to kitchen drains to enhance the sewers' natural bioremediation ability. Over the years, lab-based or full-scale addition of oil-degraders to FOG-rich wastewater has produced variable results (Mendoza-Espinosa and Stephenson, 1996; Brooksbank et al., 1997, Wakelin and Forster, 1997). Failure cases have always been associated with poor microbial adaptation to the environment, inadequate dispersion or the presence of inhibitors or toxic compounds (Watanabe et al., 2000). Notwithstanding the positive outcome of many bioaddition treatments, there is still very limited information on the science underpinning the process and, in particular on the impact of the physicochemical composition of the wastewater to treat and on how the different components could influence the bioremediation process.

For example, the degradation of triglycerides, the dominant component of FOG in kitchen wastewater (KWW), starts with a hydrolytic step mediated by lipolytic enzymes or lipases. Lipases production, can be enhanced (Hasan et al., 2006), reduced or completely inhibited by particular carbohydrates and organic nitrogen sources and concentration (Eltaweel et al. 2005; Ertuğrul et al. 2007; Takaç \& Marul 2008). Rathi et al. (2001) found optimum lipolytic activity from Burkholderia cepacia at $1 \%$ glucose over a test range of $0.25-2.5 \%$ in the presence of $1.5 \%$ oil. El-Shafei and Rezkallah (1997) reported changes in lipase activity from two Bacillus spp. when fodder yeast medium was supplemented with glucose. In particular, lipase production was completely inhibited at the low and high concentrations with an optimum at $0.6 \%$. Besides these responses, lipase production does not necessarily lead to microbial removal of hydrolysed free fatty acids. In a mixed bacterial culture, Tzirita and Quilty (2009) determined that 
Bacillus species were responsible for lipase production, but only non-lipolytic Pseudomonas putida was capable of assimilating the free fatty acids.

Another important parameter for an effective biological treatment is the carbon to nitrogen balance in the wastewater, expressed as COD: $\mathrm{N}$ ratio. Microorganisms utilise carbon substrates through oxidation as a source of energy (catabolism) or, together with nitrogen, for growth and protein formation (anabolism). Under balanced nutritional conditions catabolism and anabolism are tightly coupled such that the amount of energy generated by carbon oxidation is dominantly used to fuel growth, leading to cell growth yields near maximum theoretical values. Typically a COD: $\mathrm{N}$ ratio of $20: 1$ is recommended for efficient treatment of WW of domestic composition (Grady et al., 2011). This ratio provides enough carbon to allow all available nitrogen to be co-synthesised into new biomass together with just the right amount of carbon energy to drive the process. Gurd et al. (2019) reported ratios of $60: 1$ and $50: 1$ for sink and mixed effluents wastewater and 75:1 for dishwasher discharges, suggesting a significant $\mathrm{N}$ deficiency for successful biological treatment leaving excess organic carbon undegraded. Nevertheless, microbial populations have the ability to adjust their metabolic processes in response to nutrient deficiency/carbon excess, whereby the balance between synthesis and energy shifts towards surplus energy production under carbon excess conditions (Dauner et al., 2001). Thus, organic matter in WW with COD:N values greater than $20: 1$, such as that discharged by commercial kitchens, can potentially be fully degraded without additional nitrogen but at reduced cellular yields. Jefferson et al. (2001), showed that an appropriate C:N balance in greywater biological treatment was able to eliminate the macronutrient-limiting conditions often hindering substrate degradation, such as in the case of fat in kitchen wastewater. Many lab-based FOG degradation studies, have used FOG as the sole carbon source (Becker et al. 1999; Loperena et al. 2006); or arbitrary concentrations of other substrates - either higher (Tano-Debrah et al., 1999), or in atypical proportions (Brooksbank et al., 2007; Tzirita and Quilty, 2012) to real wastewater conditions.

FOG management in food service establishment (FSE) kitchen wastewater is a more complex process than just lipid degradation. Most studies investigating 
multi-substrate systems, have only evaluated the impact of the presence of alternative carbon sources rather than co-monitoring their microbial uptake. The work aims to close these gaps by delivering a more thorough evaluation of bacterial response to realistic variations of each kitchen wastewater component.

\section{Materials and methods}

Chemicals were obtained from Fisher Scientific, UK unless otherwise stated.

\subsection{Bacterial inoculum and growth monitoring}

Bacillus licheniformis NCIMB 9375 was purchased from the UK national culture collection (NCIMB), selected amongst others for its high lipid-degradation ability (Voigt et al., 2007). Stock cultures were maintained on nutrient agar (Oxoid $\mathrm{CM} 0003$, ) at $4{ }^{\circ} \mathrm{C}$ and sub-cultured monthly. Bacterial growth was monitored by spread plate technique on Oxoid nutrient agar.. Cell dry weight (CDW) was determined for the glucose-only batch reactors according to standard methods. The FOG-remediation commercial bioadditive was a bacterial multi-species liquid preparation with a $0.1-1 \%$ nominal active microbial culture.

\subsection{Degradation trials}

Batches of 16-20 1 I Erlenmeyer flasks containing $500 \mathrm{ml}$ of culture media (synthetic or real wastewater) were used to monitor each condition. Flasks were dosed with $1 \mathrm{ml}$ of bacterial inoculum to achieve an in-situ dose of $5 \cdot 10^{5} \mathrm{cfu} / \mathrm{ml}$. Bacillus inocula were pre-cultured in nutrient broth to $2.5 \cdot 10^{8} \mathrm{cfu} / \mathrm{ml}$, confirmed by spread plate counting. The cultures were then incubated at $40^{\circ} \mathrm{C}$ and $150 \mathrm{rpm}$ (SciQuip Incu-Shake TL6-5R, SciQuip UK) for up to 62 hours. Triplicate sacrificial samples were removed at $8,16,38$, and 62 hours and analysed immediately for cell counts and FOG content. Further subsamples were stored at $-18^{\circ} \mathrm{C}$ for carbohydrate and TN analysis. Sterile controls were treated in the same manner without inoculation.

In order to directly compare removal of the different organic WW components, concentrations, removal rates, and bacterial growth yields were 
normalised to theoretical COD equivalents using conversion factors of 2.88, 1.07, 1.5 and 1.42 for FOG, carbohydrate, protein and biomass respectively, according to Grady et al. (2011).

\subsubsection{Synthetic wastewater}

A basal mineral medium was designed using a kitchen wastewater characterisation previously reported (Gurd et al. 2019). The synthetic KWW composition (recipe reported in table 1S) contained calcium chloride dihydrate (100 mg/l), potassium chloride $(70 \mathrm{mg} / \mathrm{l})$, magnesium sulphate heptahydrate (40 $\mathrm{mg} / \mathrm{l})$, ammonium chloride $(10 \mathrm{mg} / \mathrm{l})$, iron chloride $(0.27 \mathrm{mg} / \mathrm{l})$, zinc sulphate heptahydrate $(0.16 \mathrm{mg} / \mathrm{l})$, copper sulphate $(0.07 \mathrm{mg} / \mathrm{l})$, manganese sulphate monohydrate $(0.045 \mathrm{mg} / \mathrm{l})$, cobalt nitrate hexahydrate $(0.002 \mathrm{mg} / \mathrm{l})$ and ammonium heptamolybdate tetrahydrate $(0.001 \mathrm{mg} / \mathrm{l})$, together with a non-ionic surfactant Triton X-100 (14 mg/l). Rapeseed oil was added directly as FOG (150$800 \mathrm{mg} / \mathrm{l}$ ). Solutions of glucose, and/or cornflour (Tesco, UK) were added at varying concentrations $(100,500,1000,2000,4000 \mathrm{mg} / \mathrm{l})$ as a source of carbohydrate, whereas soy protein acid hydrolysate (SPH, Amisoy) was added mainly as nitrogen source ( the additional carbon carried by the hydrolysate was also considered in the calculations). SPH concentrations were varied (150, 300, 450 , and $600 \mathrm{mg} / \mathrm{l}$ ), to achieve initial TN concentrations of 20, 40, 60 and $80 \mathrm{mg} / \mathrm{l}$, with associated amino acid concentrations of 124, 248, 373 and $497 \mathrm{mg} / \mathrm{l}$, calculated as $82.8 \mathrm{wt} \%$ from the manufacturers' information datasheet (Sheffield Bioscience, 2014).Four trials were conducted wherein one substrate concentration was varied at a time ie. FOG, glucose, starch or organic nitrogen, whilst keeping the other parameters constant.

Flasks were autoclaved at $121^{\circ} \mathrm{C}$ for 20 minutes. Media was buffered to $\mathrm{pH} 7$ by addition of $30 \mathrm{ml} / \mathrm{l}$ of a sterile $1 \mathrm{M}$ sodium phosphate buffer after autoclaving to prevent precipitation of calcium phosphate. $30 \mathrm{mg} / \mathrm{l}$ of the anionic surfactant sodium dodecyl sulphate, at a similar concentration to that measured in real wastewater was also added post-autoclave to prevent thermal degradation. Filter-sterilised rapeseed vegetable oil (Tesco, UK) was added dropwise to the flasks with a sterile pipette. Concentrations of the organic components were 
varied to achieve the test parameters reported in Table 1 covering ranges previously determined in real KWW (Gurd et al. 2019).

Following media preparation, flasks were shaken overnight to emulsify the oil before bacterial dosing.

Table 1. Test conditions for the four experimental trials showing concentrations of individual substrates andCOD(theoretical): $\mathrm{N}$ ratios, compared to concentration ranges in real kitchen wastewater (Gurd et al. 2019).

\begin{tabular}{|c|c|c|c|}
\hline $\begin{array}{l}\text { Organic } \\
\text { substrate } \\
\text { range in real } \\
\mathrm{KWW}(\mathrm{mg} / \mathrm{l})\end{array}$ & $\begin{array}{c}\text { Organic } \\
\text { component } \\
\text { varied in the } \\
\text { test }\end{array}$ & $\begin{array}{l}\text { Test concentrations } \\
(\mathrm{mg} / \mathrm{l}) \text { and } \\
\text { COD:N ratios }\end{array}$ & $\begin{array}{l}\text { Constant } \\
\text { parameters } \\
(\mathrm{mg} / \mathrm{l})\end{array}$ \\
\hline $\begin{array}{l}\text { Total FOG: } \\
200-2000\end{array}$ & $\begin{array}{l}\text { Rapeseed oil (as } \\
\text { a model for } \\
\text { FOG) }\end{array}$ & $\begin{array}{c}150,300,450,600,800 \\
45,53,61,69,80\end{array}$ & $\begin{array}{c}\text { Glucose } 1200 \\
\text { Starch } 220 \\
\text { SPH } 400 \text { (TN 52) }\end{array}$ \\
\hline $\begin{array}{l}\text { Total } \\
\text { carbohydrate } \\
\text { (simple sugar): } \\
100-4000\end{array}$ & $\begin{array}{l}\text { Glucose (soluble } \\
\text { monosaccharide) }\end{array}$ & $\begin{array}{c}100,500,1000,2000,4000 \\
35,42,53,73,112\end{array}$ & $\begin{array}{c}\text { Oil } 580 \\
\text { Starch } 0 \\
\text { SPH } 400(\text { TN 52) }\end{array}$ \\
\hline $\begin{array}{l}\text { Total } \\
\text { carbohydrate } \\
\text { (complex): } \\
100-4000\end{array}$ & $\begin{array}{l}\text { Corn starch } \\
\text { (particulate } \\
\text { carbohydrate) }\end{array}$ & $\begin{array}{c}100,500,1000,2000,4000 \\
33,44,53,75,111\end{array}$ & $\begin{array}{c}\text { Oil } 580 \\
\text { Glucose } 0 \\
\text { SPH } 400(\text { TN 52) }\end{array}$ \\
\hline TN: 24 - 80 & $\begin{array}{l}\text { Soy protein } \\
\text { hydrolysate, } \\
\text { SPH, (as total } \\
\text { nitrogen) }\end{array}$ & $\begin{array}{c}150,300,450, \text { and } 600 \\
(\text { TN 20, 40, 60, 80) } \\
45,56,80,147\end{array}$ & $\begin{array}{c}\text { Oil } 580 \\
\text { Glucose } 500 \\
\text { Starch } 500\end{array}$ \\
\hline
\end{tabular}

\subsubsection{Real wastewater}

Kitchen wastewater was collected from a food service establishment on Cranfield University campus. The samples represented water entering the sewers from the pot-wash sink, with a capacity of about $40 \mathrm{I}$. The sampling schedule aimed at capturing effluents from a restaurant at its peak time after the lunchtime service. Sample containers were shaken vigorously to emulsify and homogenise the free FOG fraction. Subsamples of 500 or $250 \mathrm{ml}$ were transferred into conical shake flasks and inoculated with either $B$. licheniformis or a commercial bioadditive product at a dose of $5 \cdot 10^{5} \mathrm{cfu} / \mathrm{ml}$ and cultured as in the synthetic WW trials. 
COD:N ratio in the wastewater was varied by addition of starch or ammonium chloride. Composition of the different batches used are detailed in Table $2 \mathrm{~S}$ in Supplementary Material.

\subsection{FOG, proteins and carbohydrates quantification}

FOG (oil) concentration was quantified using the modified Gerber method described in Gurd et al. (2018). Briefly, $200 \mathrm{ml}$ samples were weighed into transparent polycarbonate centrifuge bottles ( $250 \mathrm{ml}$ Nalgene, Fisher UK). $1 \mathrm{ml}$ of $10 \%$ sodium caseinate solution was added to the emulsified sample, with hydrochloric acid to lower the $\mathrm{pH}$ until precipitated particle aggregation is visually confirmed, based on a 30 second mixing period. The sample is placed horizontally on a rotary shaker at $90 \mathrm{rpm}$ for 15 minutes or until the aqueous phase is clear and then centrifuged at $2000 \mathrm{~g}$ for 10 minutes (Sorvall Legend RT+, DJB labs, Newport Pagnell UK). The supernatant is discarded and $1 \%$ sodium hydroxide added to the precipitate and residual fluid to raise the $\mathrm{pH}$ to 7 to partially re-dissolve the casein generating a slurry for easy transfer.

The method then follows the Gerber method (BS ISO 2446:2008) with some modifications. The slurry is layered onto $10 \mathrm{ml}$ of sulphuric acid in a $0-1 \%$ butyrometer (Funke Gerber, VWR, UK), followed by a few $\mathrm{ml}$ of DI water that were used to rinse down the walls of the centrifuge bottle. $1 \mathrm{ml}$ of isoamyl alcohol is added and the total volume topped up with distilled water. An acid resistant bung is inserted and the butyrometer shaken vigorously for 90 seconds. The butyrometer is centrifuged in a heater Gerber unit (Funke Gerber Nova Safety, VWR, UK) for 10 minutes followed by tempering in a water bath at $65^{\circ} \mathrm{C}$ for $3-10$ minutes. An average specific gravity of $0.89 \mathrm{~g} / \mathrm{ml}$ was used for all samples. Samples harvested after 16 hours were pre-centrifuged at $10000 \mathrm{~g}$ for 20 minutes to remove bacterial biomass before the supernatant was decanted into a new centrifuge bottle for the precipitation/flocculation stage of the quantification method. FOG concentrations were converted to COD equivalents by multiplying by a factor of 2.88 (Grady et al. 2011).

Nitrogen uptake was monitored as soluble total nitrogen (TN) in samples filtered through a $0.45 \mu \mathrm{m}$ syringe filter, using a Shimadzu TOC-V analyser with a total 
nitrogen module (TNM-1). Equivalent soluble protein was calculated by multiplying by the generic nitrogen conversion factor of 6.25 for real wastewater, and specifically 6.37 in synthetic wastewater determined from the total amino acid/TN ratio for Amisoy SPH (82.8/13.0) (Sheffield Bioscience, 2014). Glucose and starch concentrations were quantified spectrophotometrically by the Dubois method (Dubois et al., 1956) with a Jenway 6300 Visible spectrophotometer at $490 \mathrm{~nm}$, with the soluble fraction filtered through a $0.45 \mu \mathrm{m}$ syringe filter. Concentrations for protein and carbohydrate were converted to COD equivalents by multiplying by 1.5 and 1.07, respectively (Grady et al. 2011). There was no obvious impact on carbs concentration measurements when either FOG or protein concentrations were varied, i.e. there was variability between samples but no trend with concentration. Initial measured concentrations correlated well with predicted concentrations based on recipe.

\subsection{Data analysis}

All measurements were conducted in triplicate, unless explicitly reported. Apart from the glucose variation trial where one batch failed, data are presented as means of triplicate independent experiments with the errors estimated in terms of the standard deviation. All numerical and statistical analyses were performed in Microsoft Excel.

\section{Results and discussion}

The impact of different bacterial dosing levels $\left(10^{4}-10^{7} \mathrm{cfu} / \mathrm{ml}\right)$ on FOG removal was tested using the reference bacteria B. licheniformis NCIMB 9375 and a commercial multi-strain bioadditive product. Bioadditive products are typically dosed at $10^{4}-10^{5} \mathrm{cfu} / \mathrm{ml}$ in commercial applications, while academic studies have employed higher starting doses, $10^{5}-10^{7} \mathrm{cfu} / \mathrm{ml}$ (Loperena et al., 2009, Tzirita and Quilty 2009).

Both $B$. licheniformis and the commercial product did not show significant differences on maximum population density after 60 hrs or FOG removal (Supplementary data. Figure 2S). 


\subsection{Influence of different initial FOG concentration}

FOG removal rates were measured in batch tests containing different initial oil concentration $(150,300,450,600$ and $800 \mathrm{mg} / \mathrm{l})$ which reflected the range observed in real KWW (Gurd et al. 2019). Log phase bacterial growth was observed during the first 8 hours in association with rapid depletion of soluble carbohydrates, whilst, except for the lower FOG concentration $(150 \mathrm{mg} / \mathrm{l})$, minimal FOG removal was observed (Figure $1 \mathrm{~A}$ ), compared to $95 \pm 4.4 \%$ extraction efficiency in control samples. Bacterial populations fell by approximately half from 8 to 16 hours before recovering as a reflection of diauxic growth as they switched from metabolising carbohydrates to FOG. This growthrelated response is consistent with previous lipolytic activity studies in multisubstrate media (Castro-Ochoa et al., 2005; El-Shafei and Rezkallah, 1997; Handelsman and Shoham, 1994; Sharma et al., 2014) suggesting a bacterial preference for co-substrates to support growth followed by a switch to FOG utilisation during stationary phase. Das et al., (2010) determined that $B$. coagulans RK-02 produced maximum lipase activity after exhaustion of glucose, which had supported log phase growth. The FOG removal data were fitted to two common enzyme kinetic models: the Michaelis Menten model and the Andrews substrate inhibition model (Supporting Material, Figure S1), and displayed a better fit for the Andrews substrate inhibition model. This yielded kinetic constants of $V_{\max } 29 \mathrm{mg} / \mathrm{I}^{*} \mathrm{~h} ; \mathrm{K}_{\mathrm{s}} 524 \mathrm{mg} / \mathrm{l} ; \mathrm{K}_{\mathrm{i}} 39 \mathrm{mg} / \mathrm{l}$ and a critical fat concentration to inhibition (when $v=V_{\max }$ ) of $143 \mathrm{mg} / \mathrm{l}$.

This degree of substrate inhibition is considerably higher than previously determined. For instance, Loperena et al. (2006) calculated a critical fat concentration of $360 \mathrm{mg} / \mathrm{l}$ for substrate inhibition to growth, over a range of initial fat concentrations from $200-1000 \mathrm{mg} / \mathrm{l}$. Whereas, Jung et al. (2002) reported a marked drop in COD removal from dairy wastewater by activated sludge from $86 \%, 75 \%$ to $0 \%$ with FOG supplementation of 400,600 and $800 \mathrm{mg} / \mathrm{l}$ respectively. 

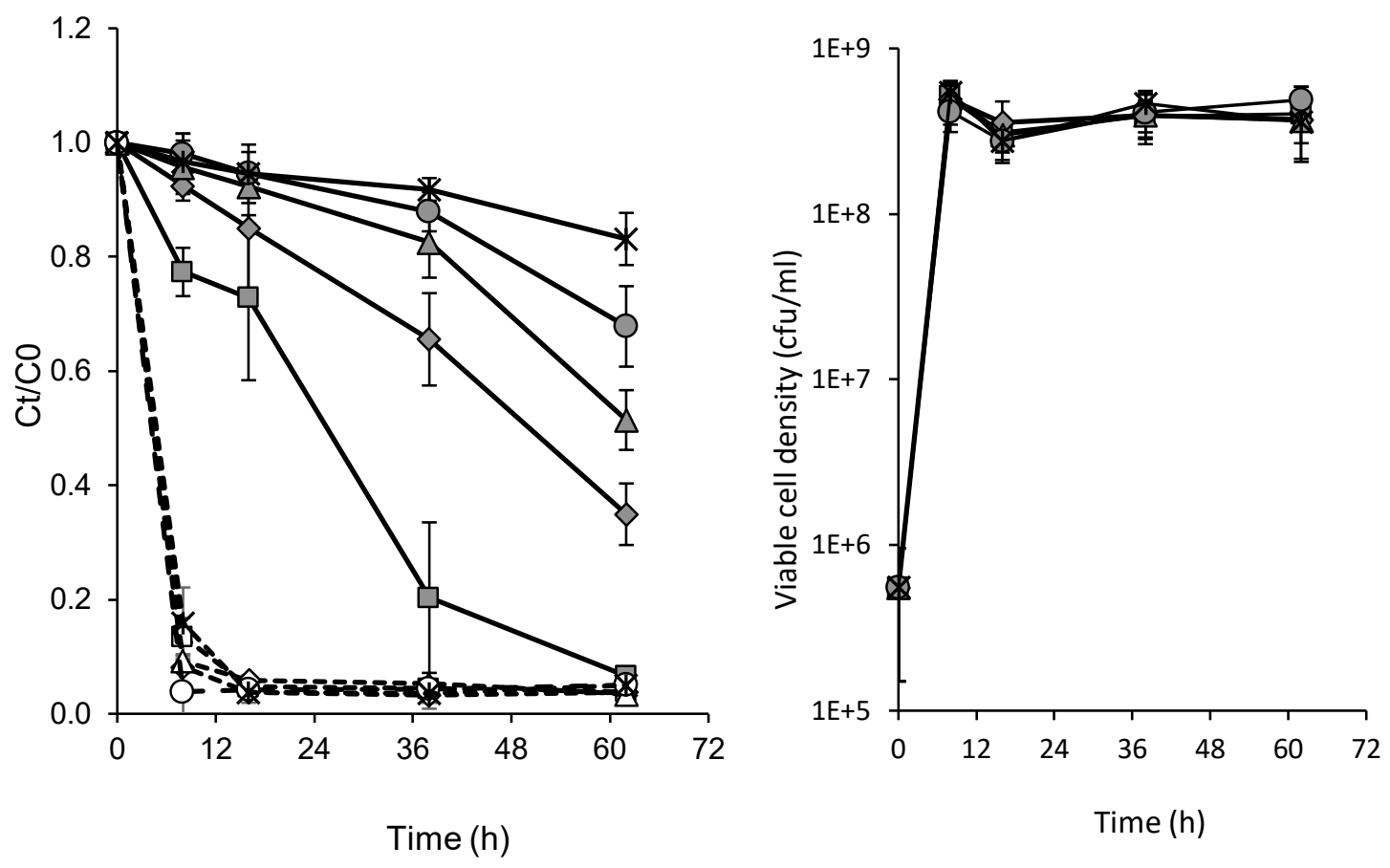

Figure 1. (A) Time course of oil removal (solid lines) and soluble carbohydrates (dashed lines), and (B) bacterial growth, for B. licheniformis 9375 dosed at 5E+5 $\mathrm{cfu} / \mathrm{ml}$ using synthetic wastewater with different initial oil concentration ( $\square 150$, $\checkmark 300, \triangle 450, \bigcirc 600$ and $* 800 \mathrm{mg} / \mathrm{l})$.

These initial results suggest the need for additional experiments to investigate the influence of the different organic fractions on FOG removal to provide an understanding of the bacterial preference for each co-substrate in relation to FOG.

\subsection{Influence of carbohydrates on FOG removal}

The rapid reduction in soluble carbohydrate, prior to the initiation of FOG removal in the experiment reported in 3.1, suggested that glucose and FOG were metabolised sequentially. Glucose is a monosaccharide and thus up-taken into the bacterial cell directly, whilst starch and triglyceride FOG molecules must first be hydrolysed by extracellular enzymes. To investigate this further, culture media were prepared with either glucose or corn starch as a source of carbohydrate. Initial concentrations of $100,500,1000,2000,4000 \mathrm{mg} / \mathrm{l}$ were used to reflect the range observed in real KWW (Gurd et al., 2019), whilst FOG, and organic N 
content remained constant (Table 1). Removal rates for each of the different organic fractions were normalised to COD units for ease of comparison.

\subsubsection{Glucose as sole carbohydrate source}

Cell dry weights (CDW) for all the glucose concentrations were determined after 8 hours, equivalent to the end of log-phase growth. Mean CDWs were fairly consistent $(0.20-0.24 \mathrm{~g} / \mathrm{l})$ in all series except for $100 \mathrm{mg} / \mathrm{l}$ which was only 0.09 g/l (COD: $\mathrm{N}$ - 25:1). Cell numbers were lowest in the $1000 \mathrm{mg} / \mathrm{l}$ series $-2.5 \cdot 10^{8}$ $\mathrm{cfu} / \mathrm{ml}$ compared to $3.6 \cdot 10^{8} \mathrm{cfu} / \mathrm{ml}$ at $100 \mathrm{mg} / \mathrm{l}$ and $6 \cdot 10^{8} \mathrm{cfu} / \mathrm{ml}$ at the higher concentrations. Cell dry weight, therefore, changed from $247 \mathrm{fg} / \mathrm{cell}$ in media with $100 \mathrm{mg} / \mathrm{l}$ of initial glucose to 359, and $321 \mathrm{fg} / \mathrm{cell}$ in media with 2000 and 4000 $\mathrm{mg} / \mathrm{l}$ of glucose respectively (Figure $2 \mathrm{~A}$ ). Optimum cell weight of $919 \pm 137 \mathrm{fg} / \mathrm{cell}$ was achieved using $1000 \mathrm{mg} / \mathrm{l}$ of glucose. Similar results were reported by Vrede et al. (2002), who also found a mean $75 \%$ cell weight decrease in C-limited bacterioplankton, and a less dramatic decrease of $35 \%$ under N-limitation compared to exponentially growing cells.

The data reported in Figure 2B shows mean observed cell growth yield (Yobs) under glucose limitation in the $100 \mathrm{mg} / \mathrm{l}$ data series as $0.76 \mathrm{mg}$-cell $\mathrm{COD} / \mathrm{mg}$ substrate COD (calculated as reported in 2.2). This is a close value to the maximum true yield for growth on carbohydrate predicted at $0.71 \mathrm{mg}$-cell COD/mg-substrate COD which is achieved through the most efficient use of carbon for growth at the optimum COD:N ratio of 20:1 (Grady et al., 2011). In the current work, carbon use efficiency during log phase growth is described by the relative uptake ratio of theoretical COD: $\mathrm{N}$ (calculated from reductions in organic components and total nitrogen over the first 8 hours) which should also be near $20: 1$ if carbon is used purely to drive growth (optimum efficiency). Figure 2B shows the lowest COD:N uptake was achieved at $25( \pm 3): 1$ in association with maximum cell yield for the $100 \mathrm{mg} / \mathrm{l}$ glucose data set (initial COD:N 35:1).. When available glucose concentrations increased above $1000 \mathrm{mg} / \mathrm{l}$ (initial COD: $\mathrm{N} \geq 53$ ), bacterial populations responded by removing more organic carbon through increasing carbon catabolism over anabolism, reflected in COD: $\mathrm{N}$ uptake increasing to $42-50: 1$, in association with cell yields dropping to $0.23 \mathrm{mg}$-cell 
COD/mg-substrate COD. A strong negative correlation $(R=-0.84)$ between Yobs and COD:N uptake illustrated in Figure 2B indicates that the parameter of COD:N uptake is a useful tool for monitoring bacterial response to available substrate in the absence of direct biomass yield measurements.

Removal rates for each of the different organic fractions in media containing glucose as a source of carbohydrates, are presented in Figures 2C and 2D.

Growth during the log phase was almost exclusively supported by the carbohydrates portion, with minimal contribution from FOG $(0-7.7 \mathrm{mgCOD} / / \mathrm{h})$. FOG removal during this phase was limited (2-12 $\mathrm{mgCOD} / \mathrm{/h}$ ), particularly in association with low bacterial populations in the $100 \mathrm{mg} / \mathrm{l}$ series, and by residual glucose availability at high initial COD: $\mathrm{N}$ in the $4000 \mathrm{mg} / \mathrm{l}$ series.

An increase in FOG removal rate had been expected in the 100, 500 and 1000 $\mathrm{mg} / \mathrm{l}$ batch reactors after the first 8 hours, once glucose had been completely exhausted, as a response to carbon limitation. However, this was not the case, (Figure 2D). As COD:N uptake during log phase in this study was in excess of the 20:1 ratio for growth requirements, it is likely that the cells had produced more readily bioavailable overflow of metabolites, such as acetate, thereby limiting the need for FOG hydrolysis. In fact, removal time-course data suggests that FOG uptake may have been delayed rather than repressed, in that uptake rates increased during the course of the experiment. For example, maximum removal rates of $8.7 \pm 0.2 \mathrm{mg}-\mathrm{FOG} / / / \mathrm{h}(24.9 \pm 0.6 \mathrm{mgCOD} / / / \mathrm{h})$ were observed between 38 and 62 hours in the $1000 \mathrm{mg}$-glucose/l series (COD:N - 53:1). Whereas, removal remained repressed at the highest concentration, reaching only $1.2 \pm 0.4 \mathrm{mg}$ FOG $/ / / h$. A similar response was reported by Thanh et al. (2010) who demonstrated that $B$. licheniformis grown on $4.4 \mathrm{mM}$ glucose $(\sim 800 \mathrm{mg} / \mathrm{l})$ secreted around half this amount as acetate and other overflow metabolites into the medium, which were subsequently consumed during stationary phase. In the glucose-limited $100 \mathrm{mg} / \mathrm{l}$ series, lower substrate consumption (estimated as $14 \pm$ $4 \mathrm{fg}-\mathrm{COD} / \mathrm{cfu} / \mathrm{h}$ ) was insufficient to generate enough maintenance energy to support stationary phase population levels, as suggested by their decline over the course of the experiment (data not shown). 
(A) Cell dry weight

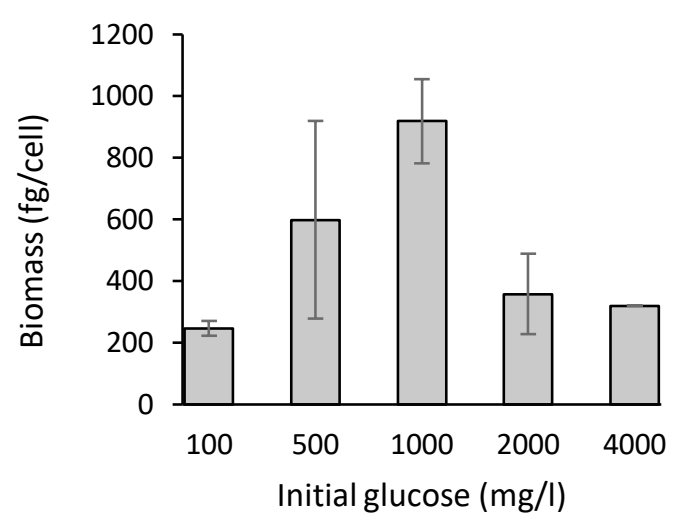

(C) Log phase

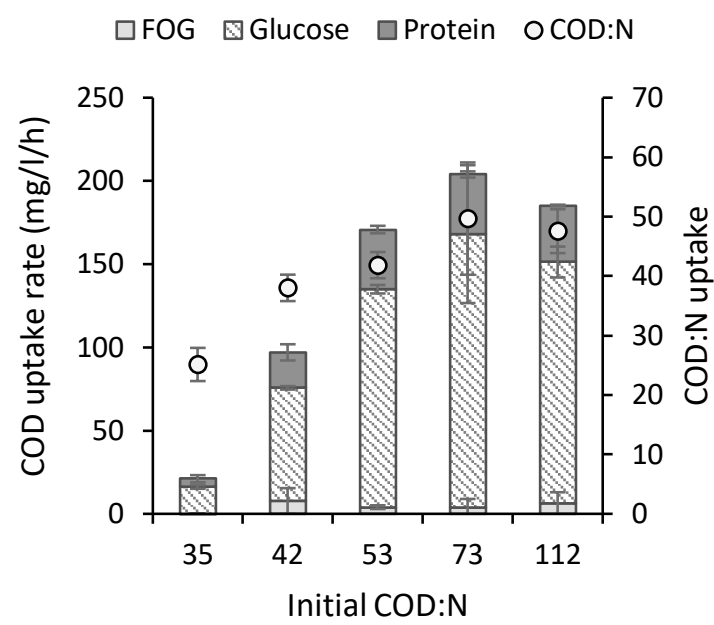

(B) Cell growth yield vs COD:N uptake

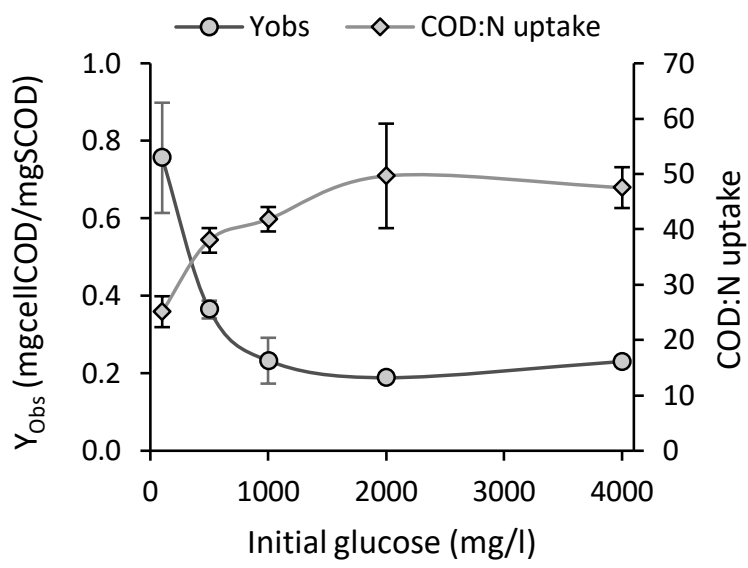

(D) Stationary phase

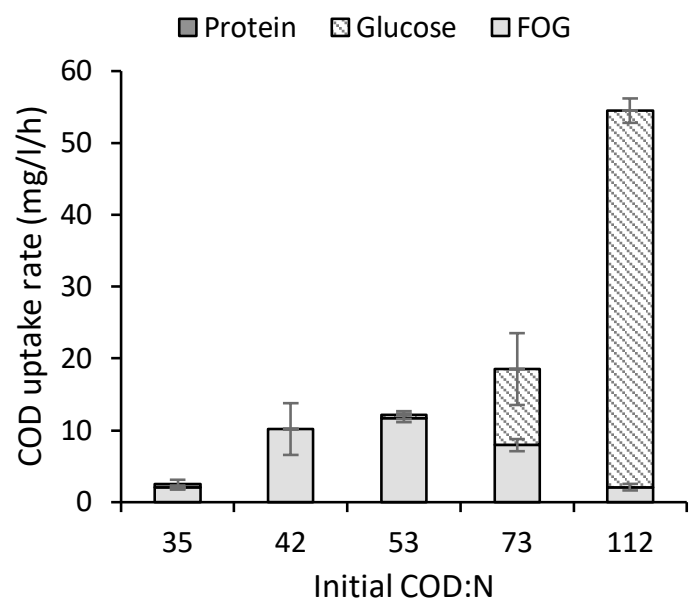

Figure 2. Influence of glucose on bacterial FOG removal in synthetic wastewater. (A) bacterial cell dry weight at different concentrations of initial glucose. (B) Comparison of observed growth yields and relative uptake of theoretical COD and $\mathrm{N}$. Theoretical COD uptake rates calculated for individual substrate fractions (bars), together with total COD:N uptake rates (circles) during $(C)$ log phase $(0-$ 8 hours) and (D) stationary phase ( 8 - 62 hours) at different initial glucose concentrations.

\subsubsection{Starch as sole carbohydrate source}

Similarly to glucose, starch-based media showed a positive correlation between increasing initial carbohydrate concentrations (and COD:N) and both COD equivalent uptake rates and COD:N uptake. Total log-phase substrate removal rates were considerably lower $(18-58 \mathrm{mgCOD} / \mathrm{l} / \mathrm{h})$ than in the presence of 
readily-metabolisable glucose $(21-204 \mathrm{mgCOD} / / \mathrm{h}$ ) (Figure $3 \mathrm{~A}$ and $2 \mathrm{C}$, respectively). However, growth on the starch media was supported by a more even consumption of FOG, starch and protein (Figure 3A). Carbohydrate uptake rates were considerably lower in starch compared to glucose media: $0.3-32$ $\mathrm{mgCOD} / \mathrm{l} / \mathrm{h}$ and $16-164 \mathrm{mgCOD} / \mathrm{l} / \mathrm{h}$, respectively.

(A) Log phase

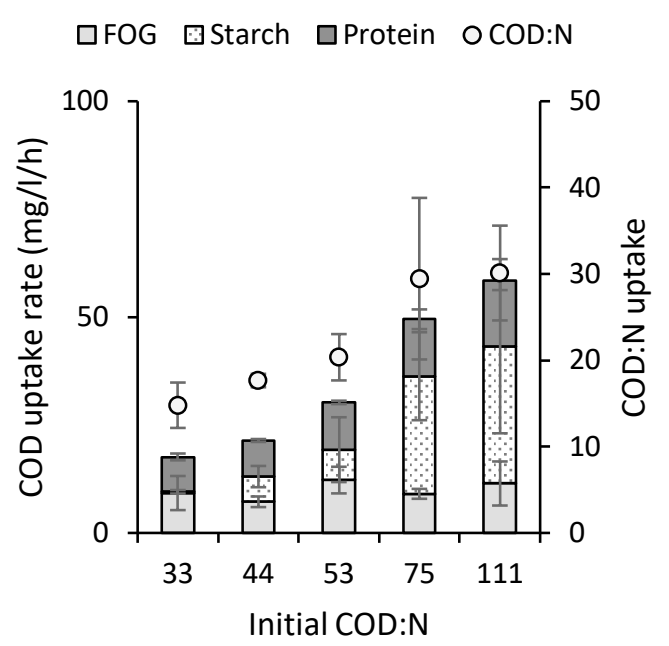

(B) Stationary phase

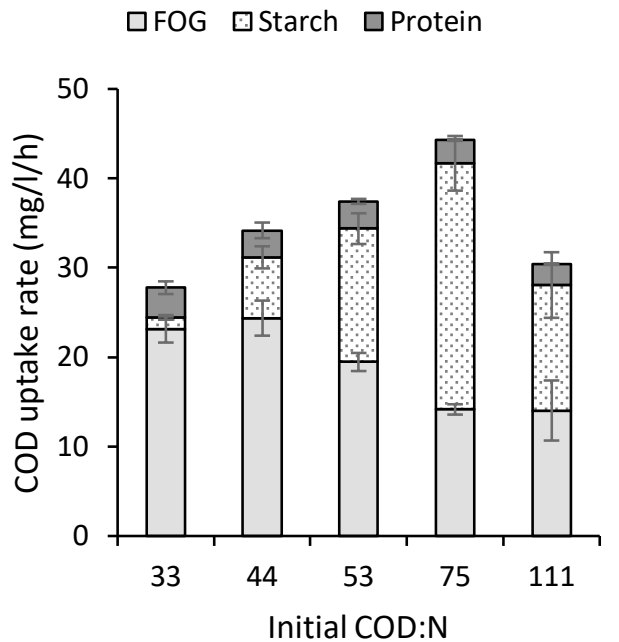

Figure 3. Influence of starch on FOG removal. Theoretical COD uptake rates calculated for individual substrate fractions (bars), together with total COD:N uptake rates (circles) during (A) log phase $(0-8$ hours) and (B) stationary phase (8-62 hours).

In addition, a minimum lag of 4 hours was observed before particulate starch began to be hydrolysed into soluble fragments $<0.45 \mu \mathrm{m}$ (data not shown).

Therefore, it is likely that early growth was predominantly supported by other readily available substrates in the media, such as amino acids. In both conditions, starch and glucose, log-phase growth was largely supported by readily available substrates, it is therefore important to evaluate the metabolism during stationary phase of growth to evaluate the real impact of carbohydrates on FOG degradation.

During stationary phase metabolism, higher FOG uptake rates in the starch media (14 - $24 \mathrm{mgCOD} / \mathrm{/} / \mathrm{h}$ ) were consistent with the production of enzymes 
associated with the metabolism of less biodegradable carbon sources in response to readily-available carbon limitation (Egli, 1995). For example, Voigt et al. (2007) demonstrated up-regulation in a number of genes associated with metabolism of alternative carbon sources, including amino acids and lipids, when $B$. licheniformis cells were subjected to glucose starvation. Total COD uptake rates were consistently higher in the starch media (28 - $44 \mathrm{mgCOD} / \mathrm{l} / \mathrm{h}$ ) resulting in stable mean stationary phase populations, with a final cell uptake rate of $45-$ $78 \mathrm{fg}-\mathrm{COD} / \mathrm{cfu} / \mathrm{h}$.

Furthermore, starch was never completely exhausted even at the lowest initial concentration: residual concentrations varied from 17 - $69 \%$ suggesting that FOG became the preferred substrate once lipolytic enzymes were produced.

Comparison of COD removal rates in Figures 2B and 3B show that carbohydrates had a strong influence on FOG degradation during stationary phase and that the carbohydrates contained in the wastewater will therefore have an impact on the outcomes of FOG bioremediation.

\subsection{Influence of protein on FOG removal}

To investigate the importance of the wastewater individual components and initial COD:N ratio, batch experiments content were conducted under the same environmental conditions as those reported in 3.2, but with media comprising of constant carbohydrate concentrations $(500 \mathrm{mg} / \mathrm{l}$ of glucose and $500 \mathrm{mg} / \mathrm{l}$ of starch) and with varying soy protein hydrolysate (SPH) to acheive TN concentrations of $20,40,60$ and $80 \mathrm{mg} / \mathrm{l}$.

Total COD uptakes rates showed a moderate negative correlation $(R=-0.67)$ with initial COD:N, linked to decreasing protein-nitrogen availability (Figure 4C). Mean stationary phase FOG uptake rates were higher than at comparable initial COD: $\mathrm{N}$ ratios in the starch media. For example 26,23 and $17 \mathrm{mg} / \mathrm{l} / \mathrm{h}$ at initial COD:N 45, 56 and 80, compared to 24, 19 and $14 \mathrm{mg} / \mathrm{l} / \mathrm{h}$ at COD:N 44, 53 and 75 in the starch media. Yet both data sets show a similar negative correlation between FOG uptake and initial COD:N. As initial carbohydrates concentration was constant, the results are a clear indication of the influence of COD:N ratio on FOG removal. Apart from the most $\mathrm{N}$-limited series (COD:N 147), N uptake 
continued beyond 8 hours. Whilst continued $\mathrm{N}$ uptake in the starch dataset was associated with an approximate doubling in cell numbers between 8 and 16 hours, cell growth in this experiment was not significant.

(A) Log phase

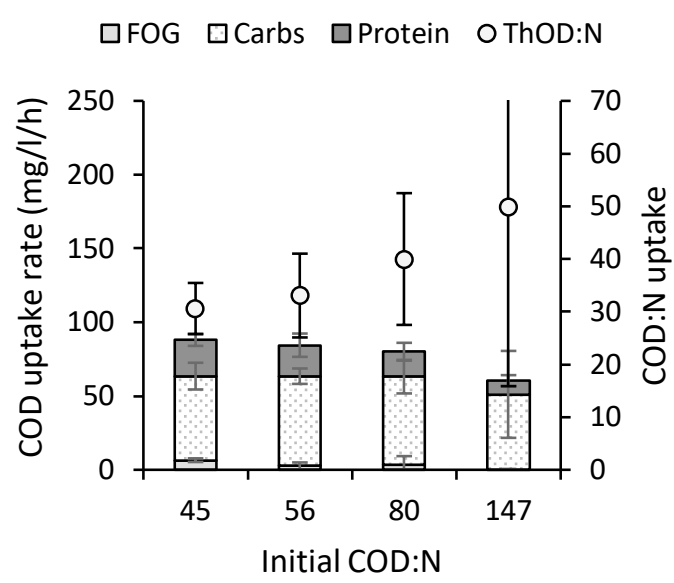

(C) Cell COD uptake

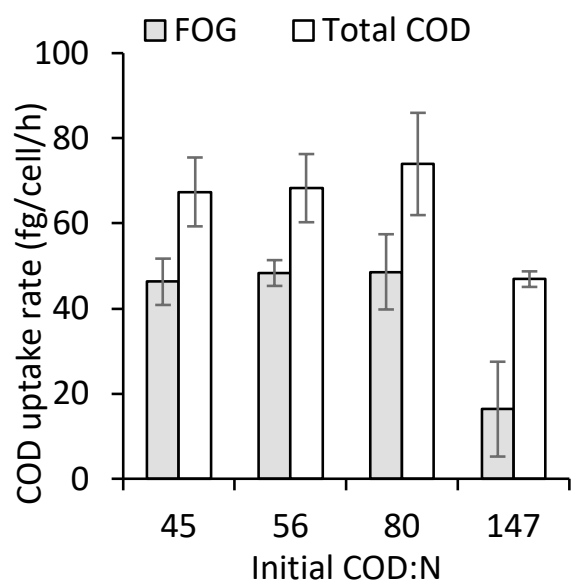

(B) Stationary phase

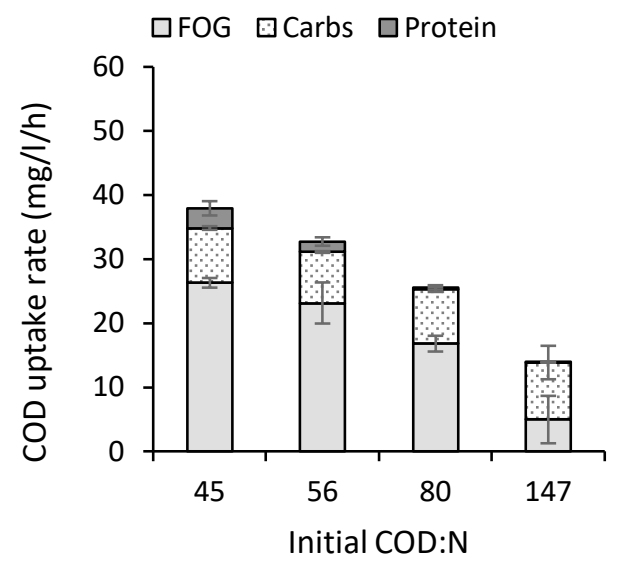

(D) Stationary phase population

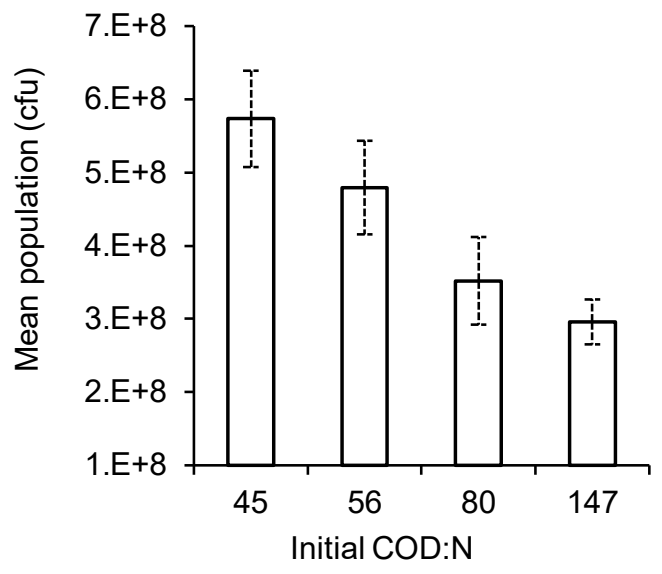

Figure 4. Influence of protein on FOG removal. Theoretical COD uptake rates calculated for individual substrate fractions (bars), together with total COD:N uptake rates (circles) during $(A)$ log phase $(0-8$ hours) and $(B)$ stationary phase ( $8-62$ hours). (C) COD uptake rates per cell in stationary phase, and (D) mean stationary phase bacterial population concentrations at different initial COD:N ratios.

Mean stationary phase populations were smaller with increasing COD:N (Figure 4D). Thus, although COD removal rates per cell were similar in COD:N 45, 56, 80 cultures ( $67-74 \mathrm{fgCOD} /$ cell/h), increasingly larger populations led to higher 
bulk removal (Figure 4C). The highest carbon-excess cultures at COD:N 147 appeared to also demonstrate a cellular response with lower total COD uptake of only $47 \mathrm{fgCOD} / \mathrm{cell} / \mathrm{h}$.

\subsection{Impact of co-substrates on FOG removal in synthetic wastewater}

$\mathrm{KWW}$ is typically rich in organic matter and relatively low in ammoniacal nitrogen compared to mixed domestic effluents with the majority of $\mathrm{N}$ provided by protein. The optimum nutrient balance for efficient WW treatment is generally assumed to occur at an initial COD:N ratio of 20:1: lower ratios are said to be carbon-limiting leaving residual nitrogen in solution, whilst higher, nitrogen-limiting ratios can be accommodated through partitioning more carbon energy into non-growth associated processes. Optimum criteria were closely met at the lowest concentration in the glucose media experiment (initial COD:N 35), wherein near maximum growth yields were achieved in association with COD: $\mathrm{N}$ removal of 25 \pm 3 . With increasing concentration, more COD energy was dissipated, -resulting in COD: $N$ uptake up to a maximum of 50:1 and lower cell yields. The same response was observed in the other experiments with starch and mixed carbohydrate compositions.

First order FOG removal rate constants (k), were calculated for all substrate conditions for the 16-62 hour time period (Figure 5). All data sets showed similar negative correlation between FOG removal and initial COD:N such that FOG uptake was favoured by more nitrogen-rich environments. FOG removal was consistently lowest in the glucose media wherein it was likely that stationaryphase maintenance energy was supplied by overflow metabolites excreted during log phase, thus delaying the need for FOG hydrolysis. Despite an initial COD:N of 35 in the $100 \mathrm{mg}$-glucose/l cultures, bacterial growth was poor due to limitation of readily-available carbon, leading to low FOG $k$ values $\left(0.001 \mathrm{~h}^{-1}\right)$ during stationary phase.

FOG $\mathrm{k}$ was up to an order of magnitude higher when glucose was replaced by starch. Maximum starch removal occurred in early stationary phase followed by a switch to FOG as the preferred substrate after 16 hours. As COD:N ratio should 
have little influence on COD uptake in stationary phase, we suggest that residual $\mathrm{N}$ availability has an influence on enzyme production which also requires a source of nitrogen. TN was removed more slowly in the starch media during log phase $(1.2-1.9 \mathrm{mg} / \mathrm{l} / \mathrm{h})$ than in glucose media $(2.6-4.1 \mathrm{mg} / \mathrm{l} / \mathrm{h}$ excluding the $100 \mathrm{mg} / \mathrm{l}$ series), leaving more nitrogen in solution. Nitrogen uptake continued throughout stationary phase whilst populations declined from a maximum at 16 hours, suggesting that $\mathrm{N}$ was used for enzyme synthesis allowing continued hydrolysis of starch and FOG. Similarly, N uptake during early stationary phase in the protein variation media was not associated with significant bacterial growth but was associated with increasing enzyme activity (Supplementary data. Figure 3S).

It appears that microbial response is governed by the ratio of readily-available carbon and nitrogen according to the model proposed by Schimel \& Weintraub (2003) developed for microbial decomposition in soils, where microorganisms are commonly limited by readily-available carbon. Those authors propose that enzyme synthesis is prioritised and biomass production will only ensue when the carbon and energy requirements for more enzyme synthesis and cellular maintenance are met. Given that FOG contains more electrons than starch as reflected in their relative COD factors (2.88 and 1.07 respectively), and thus delivers more carbon and energy by mass, it is likely that bacteria in our systems, would favour the synthesis of lipase(s) rather than starch-degrading enzymes. This would also explain the relatively higher rates of FOG uptake in stationary phase when both fractions remained.

A marked difference in carbon uptake was observed in media with easily biodegradable carbohydrate (glucose) compared to more slowly-hydrolysable starch. Nitrogen was not completely exhausted under any conditions, and thus would appear not to be a limiting factor (data shown in figure $2 S$ ). Only $56 \pm 4 \%$ of initial $\mathrm{N}$ concentrations were removed, which is consistent with the proportion of free amino acids in the soybean protein hydrolysate used for the media (Sheffield Bioscience, 2014). This indicates that the remaining $40 \%$ of nitrogen, available in the form of peptides, was less accessible for microbial uptake and anabolism. These results suggest that, biodegradability of both organic carbon 
and nitrogen should be considered when evaluating microbial response to COD:N.

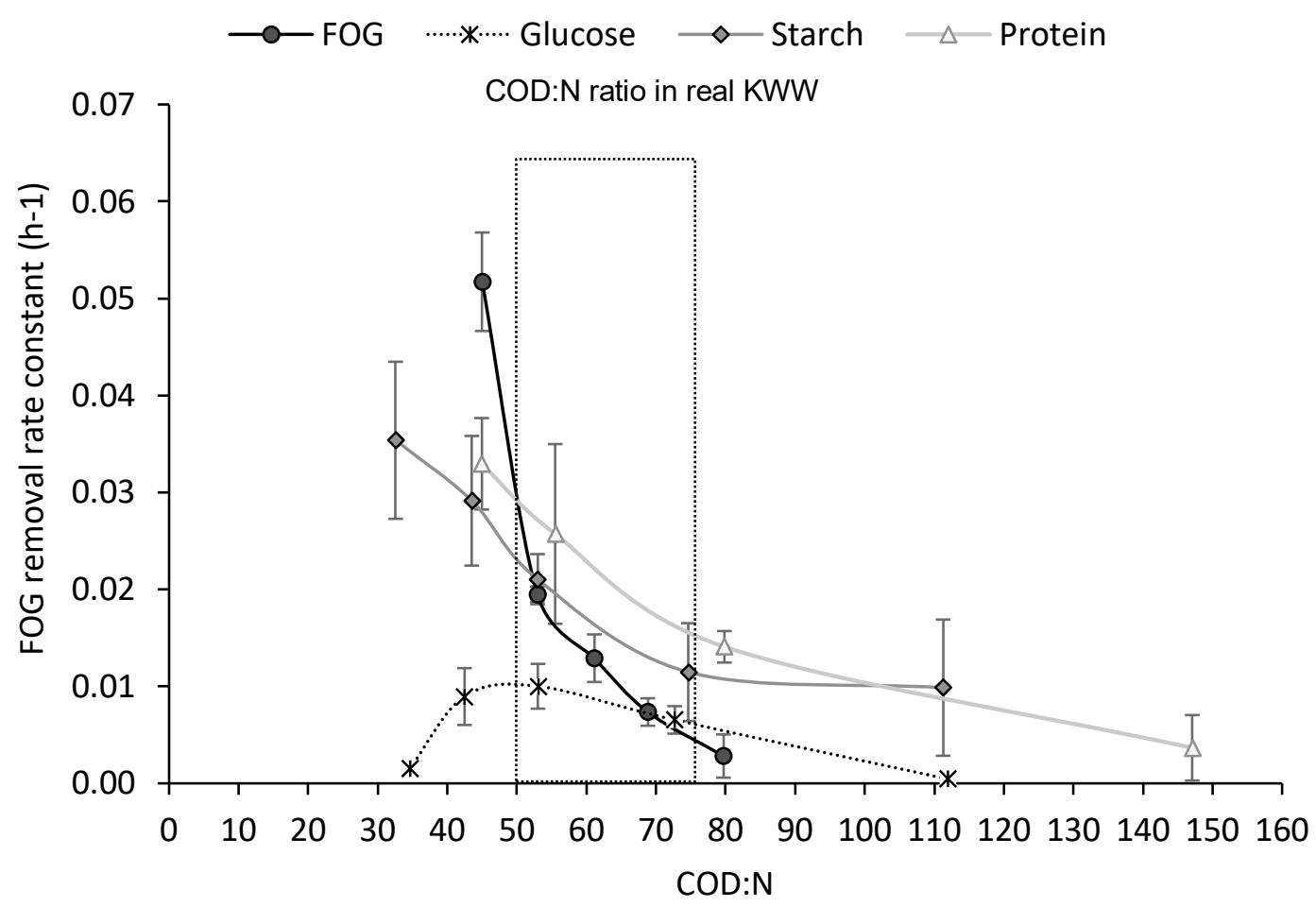

Figure 5. First order FOG removal rate constants (16 - 62 hours) in synthetic media with varying concentrations of either FOG, glucose, starch or protein resulting in a range of initial COD:N

\subsection{Bioadditions performance in real kitchen wastewater}

To validate our results, degradation experiments were conducted using real kitchen wastewaters (from a food service establishment on campus, with composition comparable to that reported previously in Gurd et al. 2019) dosed with either Bacillus licheniformis or a commercial bioadditive product Variability was observed in the FOG removal profiles which was likely due to difficulties in achieving an initial homogenous distribution of FOG between sub samples taken from the bulk sample. FOG removal rate constants $(k)$ were calculated for the whole experimental period ( 0 - 62 hours) to normalise the unavoidable variations of real KWW. Initial theoretical COD:N ratios were estimated using COD conversion factors for FOG, carbohydrate and organic nitrogen measurements 
as reported in 2.5, and were further varied by addition of starch or ammonium chloride (See Table $2 S$ in supplementary material for details of substrate composition). FOG removal response for the commercial bioadditive in real WW showed a negative relationship with initial COD:N, following a parallel trend line to experiments with Bacillus in synthetic WW (Figure 6).. . FOG $\mathrm{k}$ was lowest towards COD: $N \geq 117: 1$ for both the commercial product and Bacillus in real WW, and were not significantly different to results in synthetic media at COD:N 147,

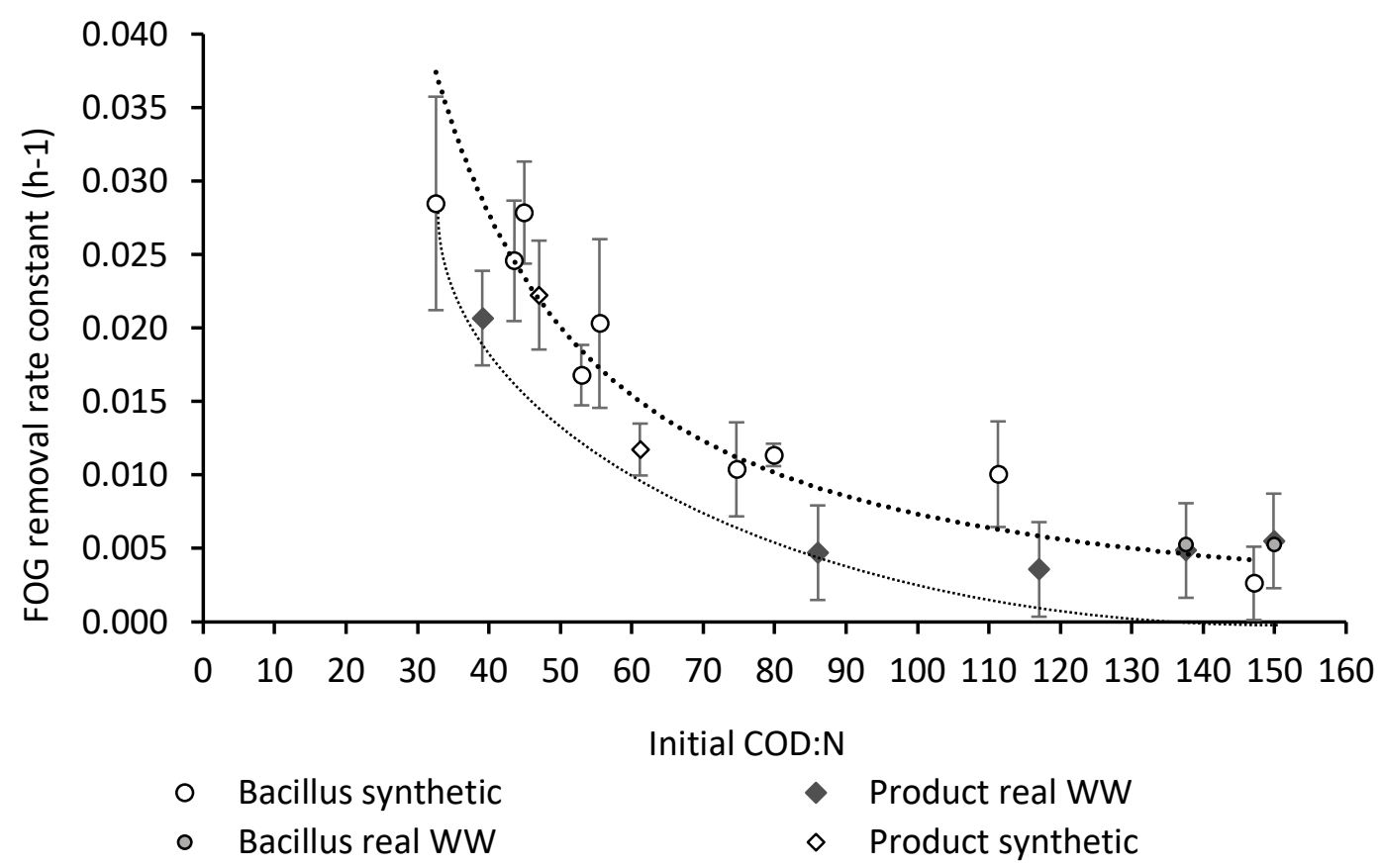

Figure 6. FOG removal rate constants for $B$. licheniformis and a commercial bioadditive product in real and synthetic wastewaters with varying COD:N ratios.

Furthermore, FOG $\mathrm{k}$ for commercial product cultures in the test protocol synthetic composition lay on the real WW trend line at COD:N 61, and the value of 0.0222 $\mathrm{h}^{-1}$ at COD:N 47 was also not significantly different from real WW $-0.0207 \mathrm{~h}^{-1}$ at COD:N 39.

Using synthetic and real wastewaters of varying compositions, a clear negative relationship was determined between FOG removal and initial COD:N over a range of 33:1 to 150:1. FOG removal rate constants were comparable in synthetic and real WW with similar COD:N for cultures of Bacillus licheniformis NCIMB 9375, and a commercial bioadditive product. Results are reported in Figure 6. Overall the data suggest that FOG removal in our synthetic media and test 
bacteria, is representative of that achieved in real kitchen wastewaters of varying compositions: the dominant influence being the initial ratio of COD:N.

\subsection{Implications for biological remediation}

In addition to high concentrations of fat, oil and grease (FOG), wastewater from food service establishments contains high quantities of carbohydrates and proteins, which could also contribute towards blockages in sewer networks. As previously reported, COD:N ratios in FSE WW can vary from 30:1 to 150:1 (Gurd et al. 2019). These values are considerably higher than the reported optimum ratio of 20:1 for wastewater degradation. Carbohydrates and organic nitrogen are also known to impact on the ability of microorganisms to degrade complex organics, such as FOG. This can have obvious implications for their biological remediation of kitchen wastewater and hence FOG deposition in the sewage system. Our results has demonstrated the importance of COD:N on FOG removal. COD:N ratio was the dominant influence on FOG removal in both synthetic and real WW. The traditional accepted ratio for successful biological treatment is $20: 1$ - the optimum balance between carbon energy and nitrogen to produce new biomass. However, this work showed that populations could respond to carbon excess by altering their metabolic processes to use carbon less efficiently resulting in relative COD and $N$ uptake of up to 50:1 - well in excess of growth requirements. Notwithstanding, barely any FOG COD was removed in association with bacterial growth with populations showing a preference for easily-metabolisable organic matter such as glucose or free amino acids. Instead FOG removal was initiated after around 14-16 hours as populations reached the stationary phase. Higher FOG removal rates were observed in media with lower initial COD:N ratios where residual nitrogen remained available beyond log-phase for the production of FOG-degrading hydrolytic enzymes during stationary phase which allowed for continued FOG removal to support cell maintenance.

This study highlights the importance of KWW characterisation. Although WW composition is highly variable day to day, water composition (COD:N:P) and FOG concentrations should be tested before starting to use bioadditives. This will help 
to identify emissions from specific premises and adjust their composition accordingly. For example, adding nitrogen compounds to mitigate carbon excess conditions in kitchen WW can enhance microbial FOG degrading ability. However, as COD:N ratios below 20:1 can also impact negatively on treatment, it is important to gauge likely site-specific ranges when devising bespoke FOG management solutions to prevent over-dosing of nutrients.

The suppression effect of glucose on FOG degradation at any concentration tested suggests that bioadditive treatment may not be an appropriate option for wastewaters from sugar-based industrial manufacturing, whilst low-sugar, starchbased compositions may be more appropriate.

Another important implication of this work is related to bioremediation requirements for contact time. The present work identified that FOG removal does not begin until stationary phase under any of the substrate conditions tested, with a lag time of at least $14-16$ hours. This suggests that there may be a requirement for a pre-culturing phase prior to dosing in a separator/trap or on-line in sewers to initiate lipase production. Indeed, some bioadditive systems are designed to administer the product following pre-culturing in a separate tank. However, the ability of bacteria to form biofilms on waste pipe walls also allows them to exist as 'pre-activated' populations in a variety of physiological states including stationary-phase state (Rani et al., 2007). Biofilms initially form because many bacteria have hydrophobic cell surfaces and thus they are attracted to surfaces by electrostatic interactions (Arnaouteli et al., 2016). FOGs are also hydrophobic and tend to adhere to the pipe walls. This brings FOG in direct contact with the biofilm layer thereby increasing contact time indefinitely provided they can be degraded at less than, or the same rate, as deposition.

In this work, highest FOG removal rates for $B$. licheniformis of $8-9 \mathrm{mg} / / \mathrm{h}$ were observed in media with different compositions mixed at COD:N ratios of 56:1 and $45: 1$ respectively, and at $9.5 \pm 0.4 \mathrm{mg} / / / \mathrm{h}$ at COD:N 42:1. FOG degradation rates needs to be at least equal to adherence rates on a biofilm surface to prevent net accumulation of deposit. Although this was beyond the scope of this work it is assumed that these conditions will be met during periods of inactivity in the kitchen, such as overnight. 
Investigations into microbial removal of organic matter in sewer environments has found biofilms show a high degree of metabolic activity and extracellular enzymes activity, with cell counts in the biofilm layer higher than in those in activated sludge wastewater treatment plants (Chen et al., 2003; Lemmer et al., 1994, Hassard et al. 2018). Moreover, (Chen and Leung, 2000) determined that oxygen uptake rates and ATP contents were twice as higher in sewer sediments than in the sewage phase indicating that biofilm populations levels and microbial activity were double those in the wastewater phase. By inference, FOG removal rates in drain pipes might be three times higher than those observed in the aqueous phase in this work.

\section{Conclusions}

Kitchen wastewater composition had a strong influence on bioremediation outcomes, explaining why laboratory and full-scale studies on bioadditions often have inconsistent results. COD:N was evaluated over a wide range of values, from traditionally accepted optimum conditions (20:1), up to 150:1, to represent more challenging conditions. A strong negative correlation was identified between bacterial cell yields and COD: $\mathrm{N}$ uptake. The current work has also demonstrated the importance of the COD:N on FOG removal. Higher FOG removal rates were observed in media with lower COD:N. For example, uptake rates per cell were similar over a COD:N range $45-80$ but population levels decreased which translated into lower overall FOG uptake. At highest tested ratio (147) there was a 3-fold decrease in per cell uptake, together with smaller populations overall FOG uptake 5 times lower than at COD:N 45. Finally, FOG removal was suppressed in the presence of glucose, by low bacterial populations at low glucose concentrations, and residual glucose at higher concentrations, but increased with increasing organic nitrogen content. Although WW composition is highly variable day to day, water composition (COD:N) and FOG concentrations should therefore be tested before starting to use bioadditives to limit process failure. 


\section{Acknowledgments}

The authors gratefully acknowledge financial support from the Engineering and Physical Sciences Research Council (EPSRC) through their funding of the STREAM Industrial Doctorate Centre (Grant no. EP/L015412/1) and from FOG Ltd. All data supporting this study are openly available from the Cranfield University repository as https://doi.org/ 10.17862/cranfield.rd.7731530.

\section{References}

Arnaouteli, S., MacPhee, C.E., Stanley-Wall, N.R., 2016. Just in case it rains: building a hydrophobic biofilm the Bacillus subtilis way. Current Opinion in Microbiology. 34, 7-12.

Becker, P., Köster, D., Popov, M., Markossian, S., Antranikian, G. and Märkl, H., 1999. The biodegradation of olive oil and the treatment of lipid-rich wool scouring wastewater under aerobic thermophilic conditions. Wat. Res. 33(3), 653-660.

Brooksbank, A.M., Latchford, J.W. and Mudge, S.M., 2007. Degradation and modification of fats, oils and grease by commercial microbial supplements. World J. Microbiol. Biotechnol. 23(7), 977-985.

Castro-Ochoa, L.D., Rodríguez-Gómez, C., Valerio-Alfaro, G. and Oliart Ros, R., 2005. Screening, purification and characterization of the thermoalkalophilic lipase produced by Bacillus thermoleovorans CCR11, Enzyme Microbial Technol. 37(6), 648-654.

Chen, G.-H., Leung, D.H.-W., 2000. Utilization of oxygen in a sanitary gravity sewer. Water Research. 34(15), 3813-3821.

Chen, G.-H., Leung, D.H.W., Hung, J.-C., 2003. Biofilm in the sediment phase of a sanitary gravity sewer. Water Research. 37(11), 2784-2788.

Das, S., Kharkwal, S., Pandey, S.K. and Sen, R., 2010. Multi-objective process optimization and integration for the sequential and increased production of biomass, lipase and endospores of a probiotic bacterium, Biochemical Eng. J. 50(1-2), 77-81.

Dauner, M., Storni, T., Sauer, U., 2001. Bacillus subtilis metabolism and energetics in carbon-limited and excess-carbon chemostat culture. J. Bacteriol. 183(24), 7308-7317.

Dubois, M., Gilles, K.A., Hamilton, J.K., Rebers, P.A. and Smith, F., 1956. Colorimetric method for determination of sugars and related substances, Anal. Chem. 28, 350-356.

Egli, T., 1995. The Ecological and Physiological Significance of the Growth of Heterotrophic Microorganisms with Mixtures of Substrates, in Springer, Boston, MA, pp. 305-386. 
El-Shafei, H.A. and Rezkallah, L.A., 1997. Production, purification and characterization of Bacillus lipase. Microbiol. Res. 152(2),. 199-208.

Eltaweel, M. a, Noor, R., Raja, Z., Rahman, A., Salleh, A.B. and Basri, M., 2005. An organic solvent-stable lipase from Bacillus sp. strain 42. Annals Microbiol. 55(3), 187-192.

Ertuğrul, S., Dönmez, G. and Takaç, S., 2007. Isolation of lipase producing Bacillus sp. from olive mill wastewater and improving its enzyme activity. J. Haz. Mat. 149(3), 720-724.

Grady, C.P.L., Daigger, G.T., Love, N.G. and Filipe, C.D.M., 2011. Biological wastewater treatment. IWA Publishing.

Gurd, C., Jefferson B. and Villa R. 2019. Characterisation of food service establishment wastewater and its implication for treatment J. Env. Man. 252, 109657

Gurd, C., Jefferson, B., Villa, R. and De Castro Rodriguez, C., 2018. Determination of fats, oils and greases in food service establishment wastewater using a modification of the Gerber method. Water Env. J. doi:10.1111/wej.12431

Handelsman, T. and Shoham, Y., 1994. Production and characterization of an extracellular thermostable lipase from a thermophilic Bacillus sp. J. Gen. App. Microbiol. 40(5), 435-443.

Hasan, F., Shah, A.A. and Hameed, A., 2006. Influence of culture conditions on lipase production by Bacillus sp. FH5. Annals Microbiol. 56(3), 247-252.

Hassard, F., Biddle, J., Harnett, R., Stephenson,T., 2018. Microbial extracellular enzyme activity affects performance in a full-scale modified activated sludge process. STOTEN. 625, 1527-1534.

Jefferson, B., Burgess, J.E., Pichon, A., Harkness, J., Judd, S.J., 2001. Nutrient addition to enhance biological treatment of greywater. Wat. Res. 35(11), 27022710.

Jung, F., Cammarota, M.C. and Freire, D.M.G., 2002. Impact of enzymatic prehydrolysis on batch activated sludge systems dealing with oily wastewaters. Biotechnol. Lett. 24(21), 1797-1802.

Lemmer, H., Roth, D., Schade, M., 1994. Population density and enzyme activities of heterotrophic bacteria in sewer biofilms and activated sludge. Water Research. 28(6), 1341-1346.

Loperena, L., Saravia, V., Murro, D., Ferrari, M.D. and Lareo, C., 2006. Kinetic properties of a commercial and a native inoculum for aerobic milk fat degradation. Bioresour. Technol. 97(16), 2160-2165.

Loperena, L., Ferrari, M.D., Díaz, A.L., Ingold, G., Pérez, L.V., Carvallo, F., Travers, D., Menes, R.J., Lareo, C., 2009. Isolation and selection of native microorganisms for the aerobic treatment of simulated dairy wastewaters. 
Bioresour. Technol. 100 (5), 1762-1766.

Mendoza-Espinoza, L., Stephenson, T., 1996. Grease biodegradation: is bioaugmentation more effective than natural populations for start-up? Wat. Sci. Technol. 34, 303-308.

Montefrio, M.J., Xinwen, T. and Obbard, J.P., 2010. Recovery and pre-treatment of fats, oil and grease from grease interceptors for biodiesel production. Appl. En. 87(10), 3155-3161.

Rani, S.A., Pitts, B., Beyenal, H., Veluchamy, R.A., Lewandowski, Z., Davison, W.M., Buckingham-Meyer, K., Stewart, P.S., 2007. Spatial patterns of DNA replication, protein synthesis, and oxygen concentration within bacterial biofilms reveal diverse physiological states. Journal of bacteriology. 189(11), 4223-33.

Rathi, P., Saxena, R.. and Gupta, R., 2001. A novel alkaline lipase from Burkholderia cepacia for detergent formulation. Proc. Biochem. 37(2), 187-192.

Schimel, J.P. and Weintraub, M.N., 2003. The implications of exoenzyme activity on microbial carbon and nitrogen limitation in soil : a theoretical model. Soil Biol. Biochem. 35, 549-563.

Sharma, D., Kumbhar, B.K., Verma, A.K. and Tewari, L., 2014. Optimization of critical growth parameters for enhancing extracellular lipase production by alkalophilic Bacillus sp. Biocat. Agric. Biotech. 3(4), 205-211.

Sheffield Bioscience, 2014. Technical Manual Supplements for cell culture, fermentation, and diagnostic media

Takaç, S. and Marul, B., 2008. Effects of lipidic carbon sources on the extracellular lipolytic activity of a newly isolated strain of Bacillus subtilis. J. Ind. Microbiol. Biotechnol. 35(9), 1019-1025.

Tano-Debrah, K., Fukuyama, S., Otonari, N., Taniguchi, F. and Ogura, M., 1999. An inoculum for the aerobic treatment of wastewaters with high concentrations of fats and oils, Bioresour. Technol. 69(2), 133-139.

Thanh, T.N., Jürgen, B., Bauch, M., Liebeke, M., Lalk, M., Ehrenreich, A., Evers, S., Maurer, K.-H., Antelmann, H., Ernst, F., Homuth, G., Hecker, M. and Schweder, T., 2010. Regulation of acetoin and 2,3-butanediol utilization in Bacillus licheniformis. Appl. Microbiol. Biotechnol. 87(6), 2227-2235.

Tzirita, M. and Quilty, B., 2009. The addition of a Pseudomonas species ensures degradation of butter by a bioaugmentation product. Proceedings of the World Congress on Water Climate and Energy, 1-7.

Tzirita, M. and Quilty, B., 2012. An investigation of mixed microbial populations for use in the treatment of waste fats, oils and greases, in Mendez-Vilas, A. (ed.) Microbes in Applied Research: Current Advances and Challenges. Singapore: World Scientific, pp. 18-22.

Voigt, B., Hoi, L.T., Jürgen, B., Albrecht, D., Ehrenreich, A., Veith, B., Evers, S., 
Maurer, K.-H., Hecker, M. and Schweder, T., 2007. The glucose and nitrogen starvation response of Bacillus licheniformis. Proteomics, 7(3), 413-423.

Vrede, K., Heldal, M., Norland, S. and Bratbak, G., 2002. Elemental composition $(\mathrm{C}, \mathrm{N}, \mathrm{P})$ and cell volume of exponentially growing and nutrient-limited bacterioplankton. Appl. Env. Microbiol. 68(6), 2965-2971.

Wakelin, N.G. and Forster, C.F., 1997. An investigation into microbial removal of fats, oils and greases. Bioresour. Technol. 59, 37-43.

Watanabe, K., Miyashita, M. and Harayama, S., 2000. Population dynamics of phenol-degrading bacteria in activated sludge determined by gyr B-targeted quantitative PCR. Appl. Environ. Microbiol. 66, 3905-3910. 


\section{Supplementary data}

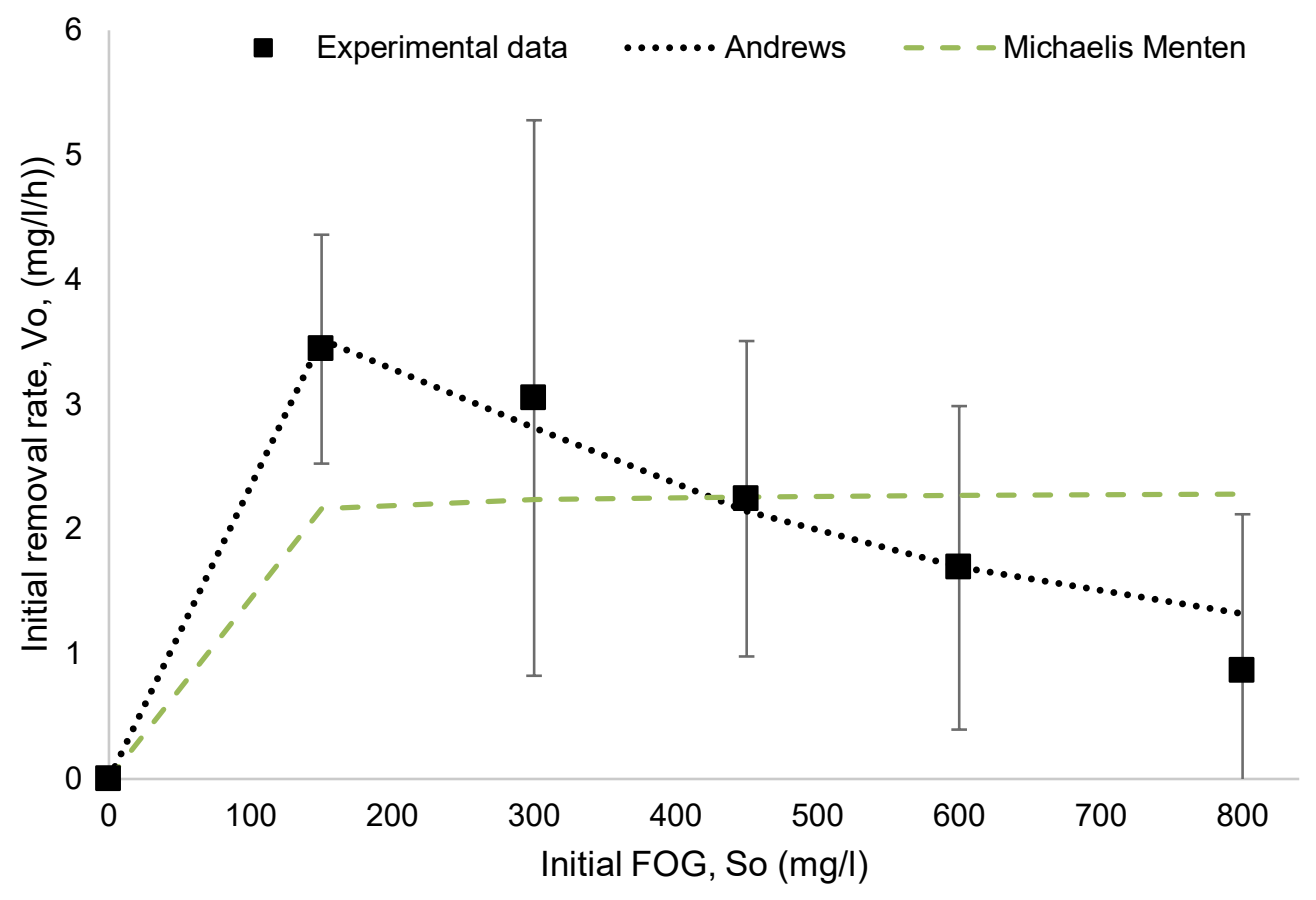

Figure 1S. FOG removal rate data fitted to the Michaelis Menten, and Andrew's substrate inhibition enzyme kinetic models calculated using 'Solver' in Microsoft Excel. Data are presented as means of triplicate independent experiments with error bars as standard deviation. 
(A) Reference bacteria: FOG and carbohydrates

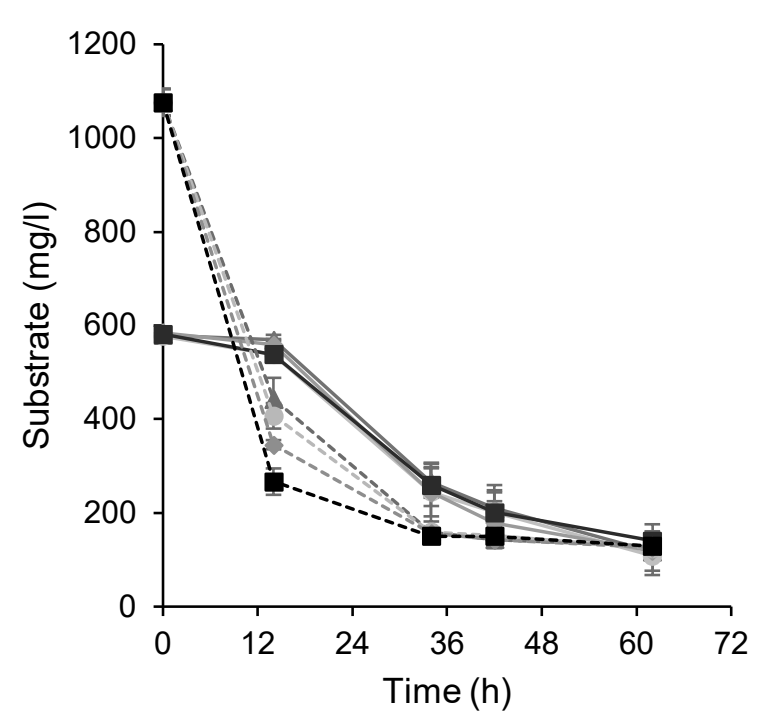

(C) Commercial product FOG and carbohydrates

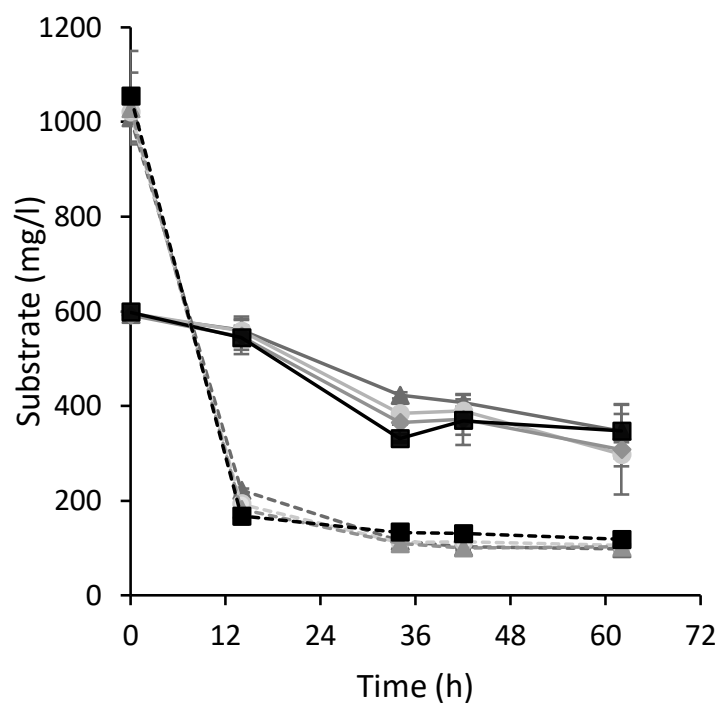

(B) Reference bacteria: TN and growth

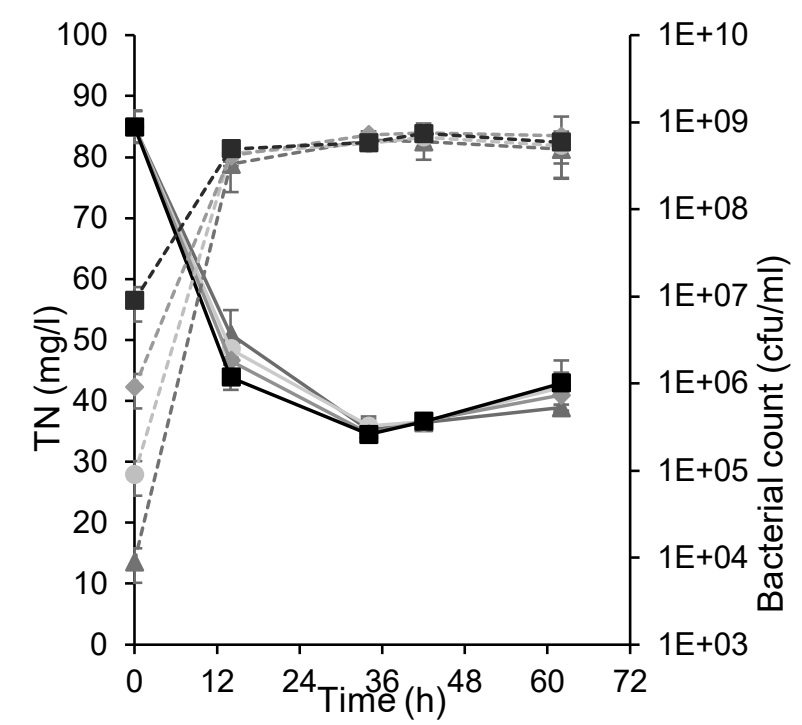

(D) Commercial product TN and growth

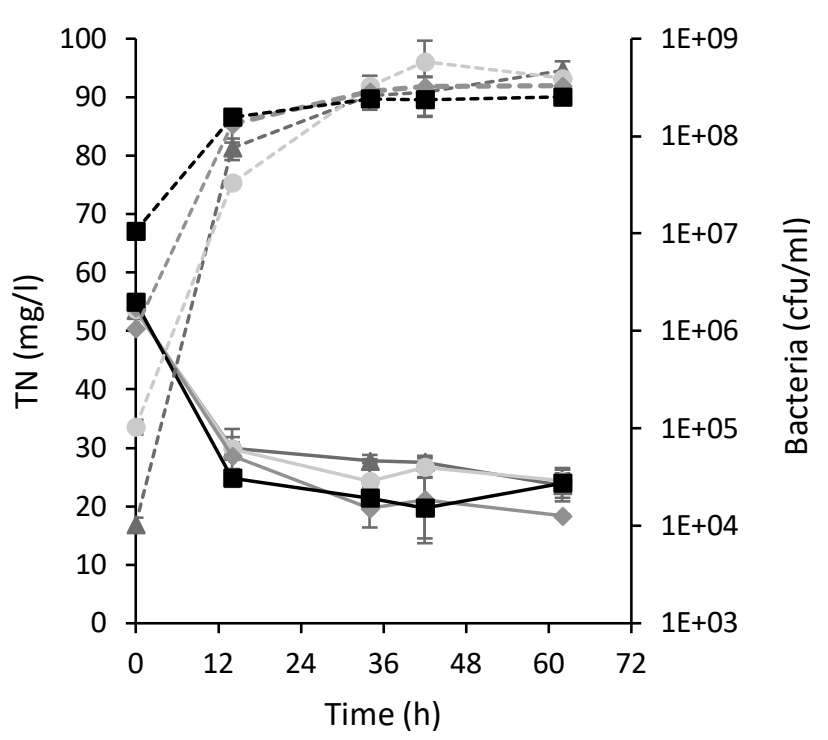

Figure 2S. Substrate removal profiles $B$. licheniformis ( $A$ and $B$ ) and $a$ commercial product (C and D) in synthetic wastewater (FOG $600 \mathrm{mg} / \mathrm{l}$, carbohydrates $500 \mathrm{mg} / \mathrm{l}$ glucose and $500 \mathrm{mg} / \mathrm{l}$ starch, soy protein hydrolysate $400 \mathrm{mg} / \mathrm{l}$ ) at different initial doses ( $\triangle 1 \mathrm{E}+04 ; 1 \mathrm{E}+05 ;$ and C) FOG removal (solid lines) and carbohydrate removal (dashed lines); (B and D) bacterial growth (dashed lines) and total nitrogen variation (solid lines). 
(A)

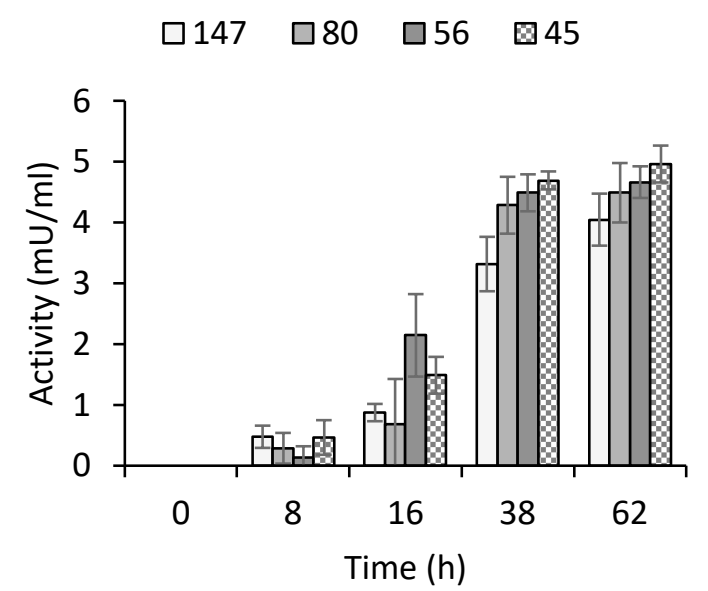

(B)

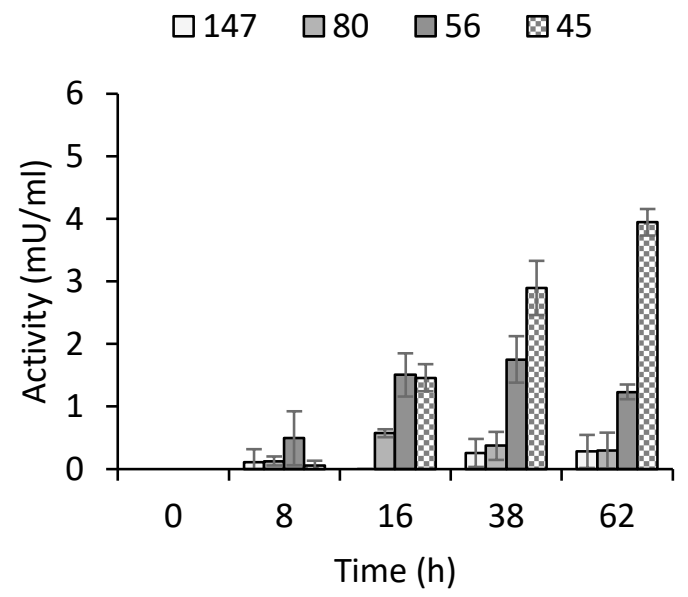

Figure 3S. Influence of varying protein concentration on FOG removal: lipase activity over time for (a) butyrate-specific enzyme and (b) octanoate-specific enzyme. 
Table 1S. Base media composition for synthetic wastewater, containing trace elements and surfactants in mean concentrations identified in real FSE wastewater (Gurd et al. 2019).

\begin{tabular}{lc}
\hline Component & Concentration (mg/l) \\
\hline Calcium chloride dihydrate & 100 \\
Potassium chloride & 70 \\
Magnesium sulphate heptahydrate & 40 \\
Ammonium chloride & 10 \\
Iron chloride & 0.27 \\
Zinc sulphate heptahydrate & 0.16 \\
Copper sulphate & 0.07 \\
Manganese sulphate monohydrate & 0.045 \\
Cobalt nitrate hexahydrate & 0.002 \\
Ammonium heptamolybdate tetrahydrate & 0.001 \\
Triton X-100 (non-ionic surfactant) & 14 \\
Added post autoclave: & \\
Sodium dodecyl sulphate (anionic surfactant) & 30 \\
Sodium phosphate buffer & $30 \mathrm{mM}$ \\
Vegetable oil (rapeseed) (Tesco) & $150-800$ \\
Soy protein hydrolysate (Amisoy) & $150-600$ \\
Cornflour - 88\% starch (Tesco) & $100-4000$ \\
Glucose & $100-4000$ \\
\hline
\end{tabular}

Table 2S. Initial concentrations of FOG, carbohydrate and nitrogen in real wastewater used in the degradation trials at different initial COD:N.

\begin{tabular}{cccc}
\hline FOG $(\mathrm{mg} / \mathrm{l})$ & Carbohydrate $(\mathrm{mg} / \mathrm{l})$ & $\mathrm{TN}(\mathrm{mg} / \mathrm{l})$ & COD:N \\
\hline $698 \pm 61$ & $222 \pm 11$ & $16 \pm 1$ & 150 \\
\hline $1141 \pm 77$ & $883 \pm 16$ & $33 \pm 1$ & 138 \\
\hline $356 \pm 78$ & $3028 \pm 236$ & $56 \pm 3$ & 86 \\
\hline $356 \pm 78$ & $3028 \pm 236$ & $* 122 \pm 6$ & 39 \\
\hline $356 \pm 78$ & ${ }^{4} 4654 \pm 186$ & $56 \pm 3$ & 117 \\
\hline
\end{tabular}

*Amended with additional ammonium chloride. ${ }^{\text {AAmended with additional starch }}$ 